Tények és vélemények a kritikai geográfiáról , a 3. Nemzetközi Kritikai Geográfiai Konferenciáról

Tér és Társadalom 17. évf. 2003/2. 93-98. p.

TÉT XVII. évf. 2003 m 2

Tények és vélemények a kritikai geográfiáról

93

\title{
A KRITIKAI FÖLDRAJZ GYAKORLATA: KÜLÖNBÖZŐ KIHÍVÁSOK KÜLÖNBÖZŐ KONTEXTUSOKBAN
}

\author{
(Critical Geographical Praxis: Different Challenges \\ in Different Contexts) \\ BLANCA RAMÍREZ
}

A 3. Nemzetközi Kritikai Geográfiai Konferencia [címben jelzett] első témaköre végiggondolására szervezett szekciók lehetöséget teremtettek arra, hogy különféle léptékekben megvitassuk a kritikai földrajzban bekövetkezett ironikus fordulatot. Az egyik legfontosabb téma - amelyet a nyitó ülésen, két hagyományos szekcióban és egy panelvitában érintettünk - annak a két közös jellemzőnek a megvitatása volt, melyen földrajzosokként osztozunk. Elöször: tudományunk elméletének és történetének a rekonstrukciója a világ két angolszász központjában, Nagy-Britanniában és az Egyesült Államokban történt meg. Így, a jelen fordulat részeként, szembesültünk azzal, hogy másutt ugyanez nem ment végbe - hiányoznak e tudománytörténetek. Másodszor: tudományunkra világszerte jellemző a konzervativizmus.

Miért ironikus a kritikai földrajzban bekövetkezett fordulat? A kérdésre természetesen több válasz is adható. Az egyik lehetséges szerint, annak ellenére, hogy a geográfia olyan tudomány, amely elkötelezett abban, hogy a világ különböző helyeinek különféle földrajzi léptékeiben gondolkodjon, mégis úgy tủnik, hogy ezt a fajta tudást csak a két központban fejlesztették ki, ezért hiányzik belőle a világról való gondolkodás mindent átfogó és magába foglaló kontextusa. Ez a kritikai és a nem kritikai földrajzot egyaránt jellemzi, és a periférián elhelyezkedő országok - még ha fejlettek is - különböző módon hatnak tudományunk elméletére és gyakorlatára.

Szekcióink célja az volt, hogy az együttlétünk adta lehetöségeket kihasználva próbáljuk megvilágítani, hogy a különbözö terek milyen esélyt adnak arra, hogy a kritikai földrajzot saját realitásaink kontextusában képzeljük el, gyakoroljuk és gondolkodjunk róla. Sok közös tendenciát találtunk hosszú és termékeny vitáink során. A központok koncentráltsága és nemzetközi jellege - egyebek mellett - az angol nyelvü publikálás kényszerében mutatkozik meg. A periféria meghaladta a fejlett és fejletlen országokra osztó hagyományos megkülönböztetést. Ez annak köszönhetö, hogy számos ország, köztük több európai is, kimaradt a tudományunk örökségét képezô saját földrajz-történeteik rekonstruálásából, és a publikálás területén is marginális szerepet játszanak. A wolfi gondolatot kölcsönözve, a „más” földrajzi szélességeken élő geográfusokat „történet nélküli embereknek és helyeknek” tekintik. Közösek a problémáink, közösen kell gondolkodnunk a megoldásukról is, ennek folyománya tapasztalataink összekapcsolásának szükségessége. 
Tények és vélemények a kritikai geográfiáról , a 3. Nemzetközi Kritikai Geográfiai Konferenciáról Tér és Társadalom 17. évf. 2003/2. 93-98. p.

94 Tények és vélemények a kritikai geográfiáról

TÉT XVII. évf. 2003

2

Megpróbálom vitáinkat e széles és közös problémakörön belül három fö kérdés köré csoportosítani: a kritikai jelentése a földrajzon belül, az elmélet és a módszertan problémája, és olyan program hiánya, amely lehetövé tenné elkötelezettségünk megkülönböztetését a hagyományos földrajztól. Hangsúlyozni kell, hogy felmerültek más témák is, de ezek inkább elszigetelt kérdésként jelentek meg a viták során, s majd a következő találkozókon kell öket mélyebben elemezni. Vannak olyan kérdések is, amelyeket a jövöben kell megválaszolnunk.

\section{Mit jelent a kritikai hozzáállás a földrajzon belül?}

Nem találtuk meg az egyértelmü jelentését a kritikai földrajznak, és azt, hogy ez hogyan kapcsolódik mindennapi életünkhöz. Megvitattuk azokat a tapasztalatokat, amelyek olyan közegből érkeztek, ahol a kritikai gondolkodásnak nagy hagyományai vannak, illetve azokat, ahol a kritikai gondolkodás egyet jelenthet az elszigeteltséggel és a tudományos és szakmai gyakorlatban való mellőzöttséggel. Egyetértettünk abban, hogy a neoliberális korban a kritikaiság szerepe drámai módon megváltozott a korábbi időszakokhoz képest, amikor a szocialista és a kommunista mozgalmak a valóság eröteljes megvilágítását támogatták, és fontos pozíciókat szereztek a földrajzon belül. Legfontosabb jellemzöjük az elmélettel, ezen belül is a marxizmussal való kapcsolat volt.

Ma a kritikai irányultság messze esik a szocializmustól és a kommunizmustól, így a marxizmustól is; többek számára azt jelenti, hogy valaki vagy valami ellen határozzák meg magukat, anélkül, hogy a folyamatokat és a tényeket mozgató valós erőket észrevennék. Az elmúlt időszakban a diskurzusok semlegesítették a konfliktusokat. Az elméletek átalakulásai, a marxista reorientációk, különösen a posztstrukturalista megközelítésekben, hozzájárultak a zavar elmélyítéséhez és a világos irány hiányához.

Némelyek számára az aktivitás és a valós társadalmi mozgalmakkal való kapcsolat az egyetlen út a kritikai lét különféle lehetöségeinek megteremtéséhez. Másoknak még mindig a szocializmus az elérendỏ cél, és ez hajt minket mind a tanári munkában, mind abban, hogy segítsünk másoknak is felismerni az ellenséget a folyamatok mögött. Ebben az összefüggésben a vita tárgya a következő: lehet-e a tanítás kritikai perspektíva? Néhányak szerint a válasz igen, mások szerint nem feltétlenül, megint mások szerint az a fontos, hogyan adjuk át a diákoknak is a kritikai elkötelezettséget. Vagyis, hogy mit tanítunk nekik és hogyan, és milyen módon tudunk igazi kompromisszumokat elérni azzal, hogy hagyjuk öket valós problémákkal foglalkozni.

Néhányan az egyetemi világ szomszédságai létrehozásának fontosságát hangsúlyozták, ezek ugyanis a kritikai földrajz megteremtésének alternatív arénái és formái. Azoknak a „láthatatlan pontoknak” a szerepét emelték ki, amelyeket az intézményesült társadalom nem érint, és nem elemez - számukra ez jelenti a kritikaiság fö jellemzőjét. De egy újabb kérdés is felmerült: csak azért, mert ezen a területen oktatunk, vagy mert „láthatatlan pontokat” érintünk, már kritikai földrajzosok va- 
Tények és vélemények a kritikai geográfiáról , a 3. Nemzetközi Kritikai Geográfiai Konferenciáról

Tér és Társadalom 17. évf. 2003/2. 93-98. p.

TÉT XVII. évf. 2003 - Tények és vélemények a kritikai geográfiáról

95

gyunk, annak ellenére, hogy továbbra is pozitivista keretekben gondolkodunk? Nem arról kellene inkább gondolkodnunk, vajon hogyan tudnánk a leíró és a pozitivista nézőpontot egy másik, kritikai nézöpontra cserélni? Olyanra, ami megtalálná az elemzési és értékelési hidakat és ellentmondásokat az általános és a különleges tendenciákon belül.

Mindez pedig azért igazán lényeges, hogy egy tudományon belüli kritikai megközelítést dolgozhassunk ki azok között, akik ilyen irányultságúak. Ebben az értelemben a kritikának két alapvető aspektusát lehet megkülönböztetni. Elöször is, nem volt számunkra világos, hogy létezik-e kritikai gondolat, vagy csak ahhoz a fajta elmélethez kapcsolódik, amelyet az elemzéshez választottunk. Ha így van, megkérdezhetjük, hogy mely elméletekhez kapcsolódva lehet a kritikai gondolkodás valóban kritikai. Különbözö-e az a különbözó helyeken? Vagy csak arról van szó, hogy az adott helyre jellemzö körülmények lehetőséget adnak arra, hogy más módon gondolkodjunk? Ezekre a kérdésekre még nem sikerült választ találni.

Másodsorban, a kritika bírálatnak, ellenállásnak vagy elítélésnek fogható fel. A problémák mögé tekintésünk módja szerint el kell fogadnunk, hogy a különbözö problémák magyarázatának különböző módjai vannak. Ugyanakkor mára elfogadható lett egy adott módszer alkalmazása a valóság elemzéséhez, meglátásához és elképzeléséhez. E helyett a megközelítés helyett azonban tudomásul kell vennünk, hogy a kritika azoknak a különböző ellentmondásoknak az analízisét és értékelését jelentheti, melyeket a különböző terek különbözỏ szereplői által alkalmazott téralkotási módokban találunk a szubjektivitás ellenére, ami a tények magyarázatának meghatározási kritériumaiban megbújik. Ez a kritikának mint a valóság felé irányuló személyes perspektívának az egyik lehetséges változata. Lehetővé teszi a dialógust a többiekkel, ahelyett, hogy nézeteiket és állásfoglalásukat helytelenítené.

Vannak-e különbözö léptékei ennek a pozíciónak a kritikában? Szerintem igen; elöször azonban azonosítani kell őket, azért, hogy egy sokkal átfogóbb megközelítést lehessen kialakítani azokról az utakról, amelyekben e gyakorlatnak különböző perspektívái vannak kontextusoktól, terektöl, idötől és persze politikától függöen, amelyben kialakulnak és fejlödnek.

\section{Esettanulmányok és az elmélet hiánya: sajátos módszertan}

$\mathrm{Az}$ esettanulmányok mindig is a földrajz szerves részét képezték, erősen kapcsolódtak a földrajzi gyakorlathoz, és a kutatásokhoz is. Hozzájárultak tudományunkban a konzervatív, pragmatikus és nem-reflexív álláspontokat támogató leíró hagyományok fenntartásához.

Valójában azonban mi, kritikai geográfusok, továbbra is reflexiók nélküli esettanulmányokként végezzük el és mutatjuk be munkáinkat, a pozitivista elemzés módszertani keretein belül. Ezen a ponton újabb kérdések merülnek fel: készíthetjưk-e ezeket az esettanulmányokat kritikai perspektívából? Egy adott elmélet felhasználása jelenti-e a problémát, vagy ez pusztán módszertani kérdés? Ha igen, hogyan lehet eltérő elméletet és gyakorlatot létrehozni? Hogyan tudunk leíró témák helyett elem- 
Tények és vélemények a kritikai geográfiáról , a 3. Nemzetközi Kritikai Geográfiai Konferenciáról

Tér és Társadalom 17. évf. 2003/2. 93-98. p.

96 Tények és vélemények a kritikai geográfiáról

TÉT XVII. évf. 2003 - 2

zöbb és elvontabb témák felé lépni? Ki és milyen célból hozza létre az elméletet? Fontos, hogy kinek a számára és miért?

Nem kategóriákkal és módszerekkel foglalkozunk, és általánosságban véve befejezzük a hagyományos és konzervatív földrajz kategóriáinak és módszereinek a használatát. Itt felmerül a kérdés: el kell-e határolnunk a módszertani kérdéseket az ideológiai háttértől annak érdekében, hogy a kritikai földrajzon belül megtaláljuk identitásunkat?

Néha olyan földrajzot rekonstruálunk, amely teljesen elszigetelt a tudomány más területeitôl. Azt hisszük ugyanis, hogy csak a geográfusok gondolkodnak a világról és a térröl, amelyben tevékenykednek, és nem veszünk tudomást - többek között az építészekről, az urbanistákról, a szociológusokról és az antropológusokról. Pedig a tơrténelem színpadán megjelenő különbözö szereplőkkel együtt ők is részt vesznek például a város építésében.

Megváltoztathatók-e az attitúdök a geográfián belül a nemzetköziség és a transzdiszciplinaritás irányába? Biztos vagyok benne, hogy igen, hiszen a földrajz hagyományosan a világ komplexitásával foglalkozik, különösen azokkal a kérdésekkel, amelyek a természet és a társadalom kapcsolatát, a terek átalakulásának megjelenítését és a tanítást érintik. Ezek pedig - véleményem szerint - a területiség bizonyos kihívásai. Vagyis azok a geográfusok, akik - jelen körülmények között a valóság komplexitását elemző transzdiszciplináris mühelymunkában más szakértỏkkel dolgoznak együtt, nehézségekkel kell, hogy szembenézzenek; meg nem oldott ügyek egész sorát adják át nekünk, amelyeket jövőbeli találkozásainkon meg kell vitatnunk.

\section{A rejtett témák és terek programja}

Hogyan tudnánk, minden különbségünk és meglévő gyakorlatunk ellenére, egy nemzetközi programot létrehozni? Nehéz kiindulópontot találni, mivel tudományunk nemzeti intézmények keretein belül fejlödik. Ennek egyik következménye a realitások széttöredezettsége, a másik pedig a folyamatok közti kapcsolatok és a cserék hiánya. Ezt a mindennapi gyakorlatban kell újra felépítenünk. A nyelv kérdése itt is nagyon fontos, hiszen a legtöbb esetben az anyanyelvünket használjuk, és az angol ,,az egyetlen nyelv”, amelynek segítségével tapasztalatot és tudást tudunk cserélni, persze korlátok között, és azoknak a kizárásával, akik nem beszélnek angolul. Ez a kérdés minden megbeszélésünkön felmerült, de a mai napig nem sikerült megfelelő megoldást találni rá.

Más gondok is vannak, amelyeket meg kellene vitatnunk. Hogyan tudjuk kutatásainkat és gyakorlatunkat a társadalom számára relevánssá tenni? Ha a kritikai földrajznak a hagyományos tudástól eltérỏ projektje van, akkor milyen ez a projekt? Van-e projektünk, vagy csak annyi, hogy az átlagos ellen fordulunk?

Marx a maga idejében nemcsak egy adott elméleti keretben való gondolkodás lehetőségét adta meg nekünk, hanem azt is, hogy elképzelhessük egy alternatív társadalom lehetőségét is. Nyilvánvaló, hogy az a projekt már véget ért, de van-e másik? Hogyan tudunk olyan kritikai gyakorlatot kialakítani, amely lehetővé teszi egy más, 
Tények és vélemények a kritikai geográfiáról , a 3. Nemzetközi Kritikai Geográfiai Konferenciáról

Tér és Társadalom 17. évf. 2003/2. 93-98. p.

TÉT XVII. évf. 2003 - Tények és vélemények a kritikai geográfiáról

97

befogadóbb világ létrehozását? Hogyan építhetnénk közösségeket vagy alternatív társadalmakat?

Termékenyebb és hatékonyabb módszereket kell találnunk a tapasztalatok, ötletek, eredmények és a társadalmon belüli változásokról szóló elképzelések cseréjére. Hogyan lehetne a szolidaritás és a csere hagyományaival rendelkezö területek (például Spanyolország és Latin-Amerika) között közös projekteket létrehozni? Hogyan tanulhatnánk mások tapasztalataiból? Lehetséges-e a „mit teszünk és mi célból” kérdés jobb megértését elősegító lételmélet vagy hibrid ismeretelmélet létrehozása?

Ki nyisson publikációs lehetőségeket? Hogyan tarthatnánk távol magunkat az intézményeink által fontosnak és hatékonynak tartott citációs index követelményétöl? Lehetséges-e a jelenleg az angolszász világban koncentrálódó publikációk decentralizácioja, hiszen nekünk, publikációs források nélküli délen élőknek csak akkor van lehetőségünk publikálni, ha angolul írunk.

Az eddig megvitatott kérdéseken kívül elkészítettünk egy nyitott program részét képező témajavaslatot, olyan témákét, amelyeket nekünk, kritikai földrajzosoknak különbözö terekben és kontextusokban elemeznünk kell, azért, hogy feltárjuk a kortárs kapitalizmus nemzetközi tendenciáit és irányát. A következő témákat tartjuk fontosnak:

1) A szegénységnek - mint az országokon belül és kívül kifejlődött globalizált jelenségnek - az eddig kifejezettektöl eltérỏ jelentése.

2) A multidiszciplináris és transzdiszciplináris megközelítések - mint módszertani fordulat - által lehetővé váló komplex valóságon belüli kapcsolatok és vonatkozások vizsgálata és értékelése.

3) Utópia és elkötelezettség, az általunk mint kritikai kutatók által létrehozni kívánt jövő részei.

4) Azoknak a tereknek a demokratizálása, ahol még mindig fontos a nyilvános és a privát terek közötti ellentmondások megvitatása.

5) Kritikai történet, amely annak az igénynek a része, hogy a földrajzi változások okait és következményeit rekonstruáljuk a nemzeti kontextusok mindegyikében.

6) A kritikai földrajz létrehozását célzó valós igény részét képező elmélet és módszertan.

7) Azok a természeti és társadalmi változások, amelyek közvetlenül kapcsolódnak a környezeti problémákhoz.

8) A tér és a társadalom kritikai ábrázolásai.

Ki kell emelnünk a globalizáció jelenleg számunkra nyújtott elönyeit - amelyek kapcsolatokat generálnak, megteremtik a csere lehetőségeit, összehoznak különbözö embereket, geográfusokat, valamint érdekeket -, mint a jelenkori kapitalizmus olyan ,juttatását”, melyet ki kell használnunk. Innen új kapcsolatokat és elkötelezettségeket lehet létrehozni, és új találkozókat, hogy folytassuk vitáinkat, és élvezzük azokat az elónyöket, amelyek segítenek elérni célunkat: hogy hozzájáruljunk egy jobb, kevésbé differenciált, ugyanakkor internacionalizált világ létrehozásához. 
Tények és vélemények a kritikai geográfiáról , a 3. Nemzetközi Kritikai Geográfiai Konferenciáról

Tér és Társadalom 17. évf. 2003/2. 93-98. p.

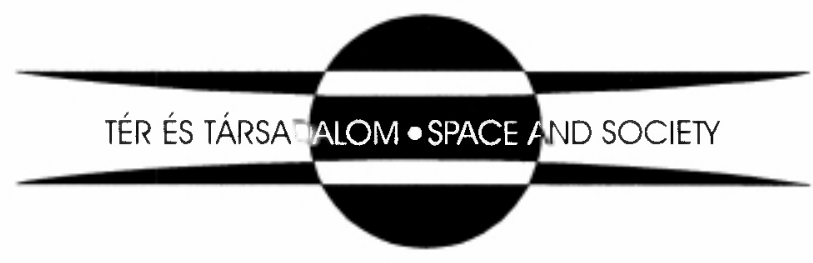

